\title{
Legemiddelsikkerhet ved bytte av digitalispreparat i Norge
}

\begin{abstract}
BAKGRUNN Etter en periode med leveringsvansker ble det eneste registrerte digitoksinpreparatet i Norge avregistert i 2011. Dette medførte at ca. 21000 pasienter måtte bytte fra digitoksin til digoksin. Det er viktige farmakokinetiske forskjeller mellom digitoksin og digoksin (samlet betegnelse på begge preparater er digitalis) som må tas hensyn til ved terapibytte. Hensikten med denne artikkelen er å oppsummere håndteringen av legemiddelsikkerhet i forbindelse med skiftet til digoksin i Norge.
\end{abstract}

MATERIALE OG METODE Henvendelser til Giftinformasjonen og fatale bivirkningsmeldinger til RELIS angående inntak av digitalis ble analysert. Serumkonsentrasjoner av digitoksin og digoksin, målt ved Oslo universitetssykehus, ble gjennomgått. Alle datakilder ble gjennomgått for årene 2010-14, og pasienter $\geq 20$ år ble inkludert.

RESULTAT Det totale antallet henvendelser til Giftinformasjonen, fatale bivirkninger rapportert til RELIS og pasientprøver i toksisk område, analysert ved Oslo universitetssykehus, $\varnothing k$ te fra 2012, i forbindelse med overgang til digoksin.

KONKLUSJON Selv med et godt informasjonsarbeid fra legemiddelmyndighetene så man en liten og forbigående økning i antall overdoseringer og rapporterte dødsfall av digitalis i forbindelse med legemiddelskiftet. Årsak til overdoseringene var i mange tilfeller ukjent. Denne studien avdekket flere tilfeller av feildosering/overdosering, samtidig bruk av digitoksin og digoksin og for kort eller manglende utvaskingstid før oppstart av digoksin.

Digitalisglykosider har vært i utstrakt bruk ved behandling av hjertesvikt og supraventrikulære takykardier, spesielt ved atrieflimmer (1). Det finnes flere digitalisglykosider som brukes medisinsk, men i Norge har det vært tradisjon å bruke digitoksin til voksne (2). Norge har således skilt seg fra resten av den vestlige verden som hovedsakelig har brukt digoksin (2). Etter en periode med leveringsvansker ble det eneste digitoksinpreparatet, Digitoxin «Nycomed», avregistrert i desember 2011.

Legemiddelmangel av enkelte preparater har vært et økende problem internasjonalt de siste årene, også i Norge. I tilfellet med digitoksin skyldes mangelsituasjonen produksjonsproblemer forårsaket av dårlig råvarekvalitet, og det var ikke mulig å få en stabil leveringssituasjon for alternative digitoksinpreparater (3). Følgelig besluttet Statens legemiddelverk (SLV) at alle pasienter som ble behandlet med digitoksin skulle konverteres til digoksin innen 1.4. 2013. Legemiddelverket informerte om dette blant annet via sine nettsider og $i$ tre utgaver av Tidsskriftet - henholdsvis i desember 2011 og i januar og mars 2012 (4-7).

Det er flere forhold knyttet til brukerne som kompliserte byttet av preparat. Pasientgruppen besto i all hovedsak av eldre personer. I forkant av byttet (2011) var $69 \%$ av brukerne av digitoksin over 75 år (8). Aldersforandringer, sykdom og samtidig bruk av andre legemidler vil også kunne påvirke effekten av digitalis. Overgang til et nytt legemiddel hos denne gruppen var derfor spesielt utfordrende.

Selv om digitoksin og digoksin har tilnærmet lik farmakodynamisk profil, er det vesentlige forskjeller i farmakokinetikk spesielt $\mathrm{i}$ distribusjon og eliminasjon og dosering for de to substansene. Doseringen av digoksin bør være lav ved nedsatt nyrefunksjon grunnet renal eliminasjon. For å kunne foreta et trygt bytte fra digitoksin til digoksin er det derfor viktig å kjenne pasientens nyrefunksjon og serumkonsentrasjonen av begge legemidlene i overgangsperioden.

Statens legemiddelverk utarbeidet en veiledning for byttet med råd om seponering av digitoksin, etterfulgt av syv dages utvaskingstid før oppstart på digoksin. Veiledende døgndose av digoksin var $0,125-0,5 \mathrm{mg}$, i tillegg til kontroll med konsentrasjonsmåling etter henholdsvis syv og 14 dager. Etter om lag to måneder ble veiledningen justert med blant annet lavere veiledende døgndose $(0,125-0,25 \mathrm{mg})$ og enda lavere dose ved moderat nyresvikt.

I fjerde kvartal 2011 var det 21246 pasienter over 20 år som fikk forskrevet digitalis $($ digitoksin $=20326$, digoksin $=920$ ), ifølge Reseptregisteret (8). I fjerde kvartal 2013, da overgangen til digoksin skulle være gjennomført, var antallet pasienter som fikk foreskrevet digitalis redusert med $25 \%$ til 16073 (digitoksin $=1525$, digoksin $=$ 14 548). Totalt antall digitoksinbrukere er $\mathrm{i}$ virkeligheten høyere da forskrivning på sykehus og i institusjoner ikke er inkludert $\mathrm{i}$ Reseptregisterets data (8).

\author{
Christian Haga \\ christian.haga@fhi.no \\ Giftinformasjonen \\ Divisjon for miljømedisin \\ Folkehelseinstituttet \\ Mimi Stokke Opdal \\ Klinisk farmakologi \\ Avdeling for farmakologi \\ Klinikk for laboratoriemedisin \\ Oslo universitetssykehus \\ Silja Skogstad Tuv \\ Klinisk farmakologi \\ Avdeling for farmakologi \\ Klinikk for laboratoriemedisin \\ Oslo universitetssykehus \\ og \\ Divisjon for rettsmedisinske fag \\ Folkehelseinstituttet
}

Per Henrik Zahl

Helseovervåkning og selvmordsforebygging

Divisjon for psykisk og fysisk helse

Folkehelseinstituttet

Hanne Stenberg-Nilsen

RELIS Sør-Øst

Avdeling for farmakologi

Klinikk for laboratoriemedisin

Oslo universitetssykehus

> Se lederartikkel side 1700

\section{HOVEDBUDSKAP}

Antall meldte forgiftninger med digitalis $ø$ kte i forbindelse med skiftet fra digitoksin til digoksin

Antall meldte dødsfall assosiert med digitalisbruk økte under skiftet, sammenlignet med årene før og etter overgang fra digitoksin til digoksin

Årsaker til overdosering kan blant annet være feildoseringer, for høy dose i forhold til nyrefunksjon og samtidig behandling med både digitoksin og digoksin 


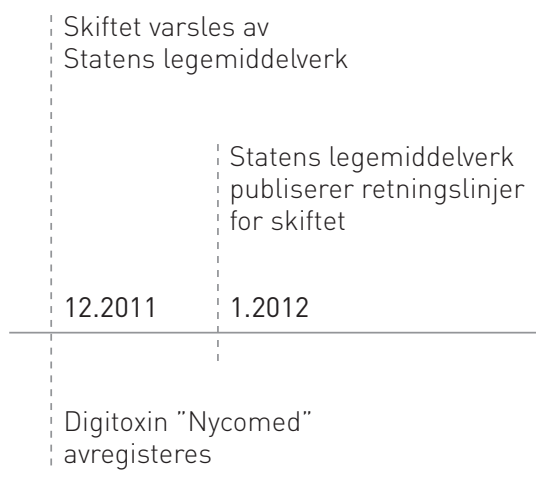

Figur 1 Tidslinje for skiftet fra digitoksin til digoksin

$\begin{aligned} & \text { Dagspressen omtaler } \\
& \text { skiftet og ett dødsfall } \\
& \text { forårsaket av overdosering }\end{aligned}$
\begin{tabular}{lll} 
& & \\
3.2012 & 1.4 .2012 & 1.4 .2013 \\
\hline & & \\
Leveringsvansker & Digitoksin kan ikke & Resepter på digitoksin \\
av digitalis antidot & lenger forskrives & er ikke lenger gyldig
\end{tabular}

Digitalispreparatene har et smalt terapeutisk vindu, det vil si at det er relativt liten forskjell mellom en serumkonsentrasjon som gir ønsket effekt (redusert AV-overledning og dermed redusert hjertefrekvens og økt myokardkontraktilitet), og en serumkonsentrasjon som gir forgiftningssymptomer (synsforstyrrelse, hjertearytmier/AV-blokk, kvalme/oppkast, mentale endringer hos eldre) (9). Terapikontroll med serumkonsentrasjonsmålinger av digitalispreparatene er nødvendig og anbefalt (10).

Hensikten med denne artikkelen er å oppsummere håndteringen av legemiddelsikkerhet i forbindelse med skiftet fra digitoksin til digoksin i Norge, basert på data fra Giftinformasjonen, fatale bivirkninger meldt til RELIS (regionale legemiddelinformasjonssentre) og serumkonsentrasjonsmålinger utført ved Oslo universitetssykehus. Ved å analysere data i perioden 2010-14 ønsket vi å se om det var en endring $i$ antall digitalisforgiftninger og dødsfall under og etter skiftet (fig 1). Vi diskuterer mulige årsaker til forgiftninger, samtidig som vi fremhever viktige punkter som man kan trekke lærdom av for fremtidige terapiendringer hos store pasientgrupper.

\section{Materiale og metode}

Dataene er hentet fra Giftinformasjonen, RELIS og Oslo universitetssykehus og inneholder ikke personidentifiserbare opplysninger. De er heller ikke koblet. Kildene gir ikke systematiske og utfyllende opplysninger om kliniske funn, utfall eller foranledning til den enkelte forgiftning. Giftinformasjonen og RELIS har landsdekkende funksjoner, mens Avdeling for farmakologi ved Oslo universitetssykehus registrerer data for inneliggende pasienter ved sykehuset og fra tilsendte prøver fra pasienter ved andre institusjoner og fra fastleger i Helse Sør-Øst. Av praktiske hensyn basert på Giftinformasjonens alderskategorisering ved registering av henvendelser ble kun personer som var 20 år eller eldre, inkludert i studien.

Basert på studier fra faglitteraturen har vi valgt å anvende etablerte grenser for serumkonsentrasjon av digitoksin/digoksin og å kategorisere $i$ henholdsvis terapeutisk, supraterapeutisk og toksisk serumkonsentrasjon $(11-13)$

Serumkonsentrasjonen må alltid ses i sammenheng med individuelle forhold hos pasienten, som alder, hjerte- og nyrefunksjon og eventuelle elektrolyttforstyrrelser, for eksempel hypokalemi.

\section{Etikk}

Prosjektet ble forelagt personvernombudet ved Oslo universitetssykehus og Folkehelseinstituttet og godkjent for publisering. Det ble ikke ansett som nødvendig å søke om godkjenning hos regional etisk komité.

\section{Henvendelser til Giftinformasjonen}

Giftinformasjonen får henvendelser fra privatpersoner (64\%), helsepersonell $(31 \%)$ og ve- terinær $(5 \%)$ for rådgivning i forhold til forgiftningsfare og behandling. Det nasjonale rådgivnings- og kompetanseorganet har kunnskap om forgiftninger med legemidler, narkotika, kjemikalier, tekniske/kjemiske produkter og planter. Organet har en landsdekkende, døgnåpen telefontjeneste som bemannes av farmasøyter, veterinærer, toksikologer og leger.

Ved henvendelse til Giftinformasjonen registreres opplysninger om pasienten (alder og kjønn), hvor henvendelsen kommer fra (helsetjeneste eller privatperson), henvendelses art (akutt inntak, kronisk forgiftning, generelle spørsmål om forgiftningsfare), hva som er inntatt, størrelse på inntaket, tid etter inntak, forgiftningsrisiko og anbefalt behandling. Ved akutte inntak registreres også årsak til eksponering (uhell, selvforskyldt/misbruk, feildosering og ukjent). Andre relevante opplysninger som symptomer/kliniske tegn og serumkonsentrasjon av legemidler registreres

\section{Antall henvendelser \\ Digoksin \\ Digitoksin}

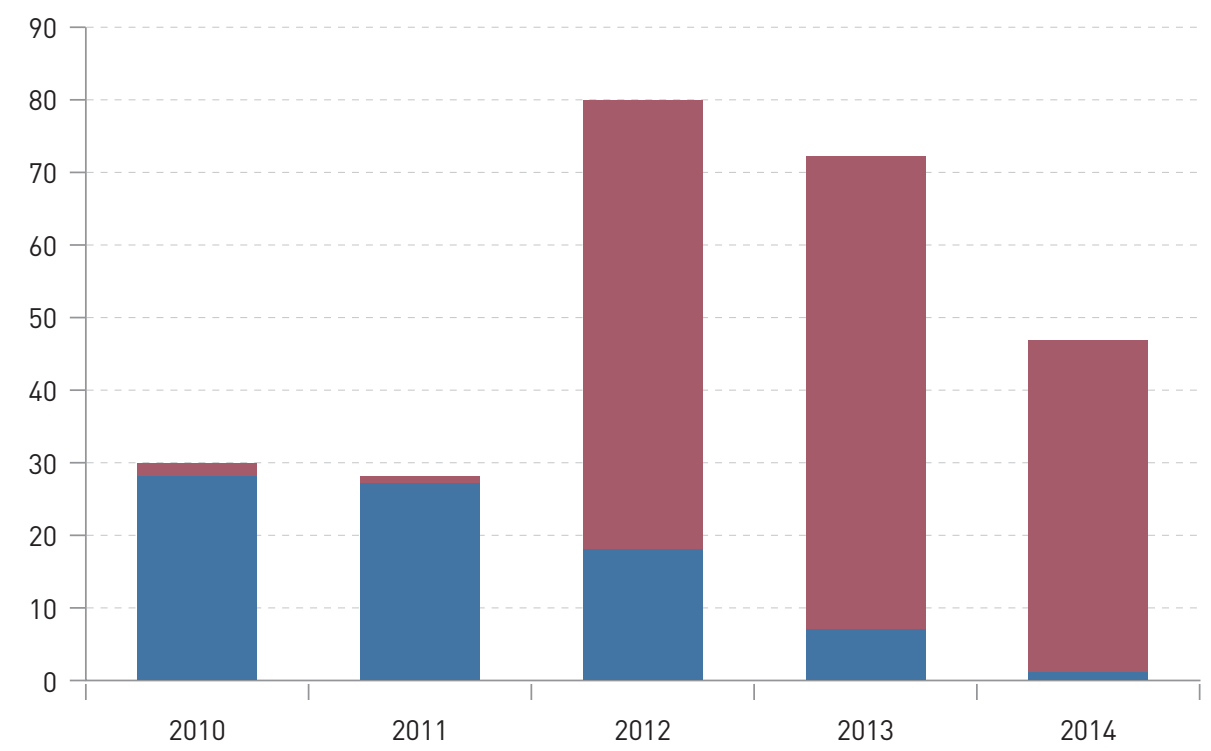

Figur 2 Antall henvendelser til Giftinformasjonen angående inntak av digitoksin eller digoksin i perioden 2010-14. En pasient kan være opphav til flere henvendelser 
Tabell 1 Fatale bivirkningsmeldinger med digitoksin og/eller digoksin som utløsende legemiddel rapportert i perioden 2010 - 14 . Meldingene er registrert i den norske bivirkningsdatabasen og årsaksvurdert av RELIS. Dataene kommer fra spontanrapportering og er innsendt av helsepersonell i alle fire helseregioner

\begin{tabular}{|c|c|c|c|c|c|}
\hline År & 2010 & 2011 & 2012 & 2013 & 2014 \\
\hline $\begin{array}{l}\text { Bivirkningsmeldinger } \\
\text { med fatalt utfall }\end{array}$ & 0 & 0 & 5 & 4 & 0 \\
\hline Utløsende legemiddel & & & $\begin{array}{l}\text { Digoksin = } 2 \\
\text { Digitoksin og digoksin = } 3\end{array}$ & $\begin{array}{l}\text { Digoksin = } 3 \\
\text { Digitoksin og digoksin = } 1\end{array}$ & \\
\hline $\begin{array}{l}\text { Redusert nyrefunksjon påvist } \\
\text { hos pasienten }\end{array}$ & & & 5 & 3 & \\
\hline
\end{tabular}

i et fritekstfelt. Personidentifiserbare opplysninger blir ikke registrert.

Data fra alle henvendelser til Giftinformasjonen vedrørende digitoksin og digoksin for årene 2010-14 ble analysert (fig 2). Antall henvendelser per år og årsak til overdosering ble vurdert. Der serumkonsentrasjon var oppgitt $\mathrm{i}$ henvendelsen, ble serumkonsentrasjonen vurdert i forhold til etablerte terapeutiske og toksiske grenser. Serumkonsentrasjoner over henholdsvis 40 $\mathrm{nmol} / \mathrm{l}$ for digitoksin og $3 \mathrm{nmol} / 1$ for digoksin ble klassifisert som toksiske (11-13).

\section{Bivirkningsmeldinger til RELIS}

Fatale bivirkningsmeldinger hvor digitoksin eller både digitoksin og digoksin var mistenkt legemiddel registrert $\mathrm{i}$ den norske bivirkningsdatabasen, og årsaksvurdert av RELIS i perioden 2010-14, ble inkludert i studien. Meldingene kom fra vanlig klinisk praksis (spontanrapporter) og var innsendt av helsepersonell i alle de fire helseregionene. Fra de inkluderte meldingene ble det registrert opplysninger om mistenkt(e) legemiddel (legemidler), indikasjon, dosering og varighet av behandling og bivirkninger, om hendelsen var relatert til bytte av preparat og/eller overdosering. Ikke-fatale hendelser ble også registrert, men er ikke inkludert i den videre analysen.

\section{Terapikontroll ved \\ serumkonsentrasjonsmåling}

Serumkonsentrasjonsmålinger av digoksin og digitoksin, analysert i perioden 1.1. 2010-31.12. 2014, ble inkludert. Prøvesvar ble tatt ut fra laboratoriedatasystemet Swisslab og lagt over i et internt kvalitetsregister.

Prøvesvar av digitoksin ble samlet for perioden 1.1.2010-31.12.2012, og prøvesvar av digoksin ble samlet for 1.1.2012-31.12.2014. Der det var flere målinger utført per pasient, ble gjennomsnitt av målingene brukt. Serumkonsentrasjonene av digitoksin og digoksin i de to periodene ble inndelt i subterapeutisk og terapeutisk, supraterapeutisk og toksisk område.

Pasienter med samtidig digitoksin og digoksin i prøven, over eller nær øvre grense for gjeldende terapiområde per år 2010-14, ble identifisert. Data ble avidentifisert før videre behandling. Forskjell i fordelingene av pasienter i de tre gruppene som brukte henholdsvis digitoksin (før terapiskifte) og digoksin (etter terapiskifte), ble testet med khikvadrattest (SPSS program).

Analysene ble utført med immunologisk metode (KIMS) på Cobas 8000, 502C, og måleområdet for metoden var henholdsvis 0,38-6,4 nmol/1 for digoksin og 6,6-85,2 $\mathrm{nmol} / \mathrm{l}$ for digitoksin. Prøver over måleområdet ble fortynnet manuelt. Ved analyse av digoksin er det oppgitt at metoden har en kryssreaktivitet med digitoksin. Ved en digitoksinkonsentrasjon på $63,9 \mathrm{nmol} / 1$ er kryssreaktiviteten $4,5 \%$ ifølge pakningsvedlegget. I pakningsvedlegget for digitoksin opplyses det om ingen kryssreaktivitet av 32 nmol/1 digoksin på digitoksinmetoden. Tidlig i 2012 ble det mistenkt at pasienter kunne ha samtidig høy serumkonsentrasjon av digitoksin og digoksin. Alle prøver med digoksinkonsentrasjon på over $3 \mathrm{nmol} / \mathrm{l}$ ble derfor analysert for digitoksin fra 19.4.2012.

\section{Resultater}

Henvendelser til Giftinformasjonen

Totalt mottok Giftinformasjonen 333 henvendelser angående digitoksin og digoksin i perioden 2010-14. Av disse ble 79 henvendelser ekskludert da inntakene kun var ett enkelt inntak av dobbel terapeutisk dose $(\mathrm{n}=38)$, eller enkelt inntak av terapeutisk dose hos ikke-bruker, normalt forårsaket av forveksling av legemidler mellom pasienter på institusjon $(\mathrm{n}=25)$. Dette er henvendelser Giftinformasjon får for praktisk talt alle lege-

Tabell 2 Antall pasienter og deres korresponderende serumnivå av digitoksin for perioden 2010 - 12 og digoksin for perioden 2012 - 14 . Totalt antall målinger hos pasienter ( $n=1619$ ) som brukte digitoksin var 3883 , hos pasienter ( $n=1058$ ) som brukte digoksin var det 2 642. Serumkonsentrasjonsnivåene i tabellen er basert på gjennomsnittsverdien i de tilfellene der det forelå flere prøver per pasient

\begin{tabular}{|c|c|c|c|c|c|c|}
\hline \multirow[b]{2}{*}{ Serumnivå } & \multicolumn{3}{|c|}{$\begin{array}{c}\text { Digitoksin 2010-12 } \\
n=1619\end{array}$} & \multicolumn{3}{|c|}{$\begin{array}{c}\text { Digoksin } 2012-14 \\
n=1058\end{array}$} \\
\hline & Antall & $(\%)$ & $\begin{array}{l}\text { Serumkonsentra- } \\
\text { sjon nmol/l } \\
\text { Gjennomsnitt (SD) }\end{array}$ & Serumnivå & Antall (\%) & $\begin{array}{l}\text { Serumkonsentra- } \\
\text { sjon nmol/l } \\
\text { Gjennomsnitt (SD) }\end{array}$ \\
\hline $\begin{array}{l}\text { Subterapeutisk og terapeutisk } \\
5-15 \mathrm{nmol} / \mathrm{l}\end{array}$ & 442 & (27) & $12(2)$ & $\begin{array}{l}\text { Subterapeutisk og terapeutisk } \\
0,4-1,3 \mathrm{nmol} / \mathrm{l}\end{array}$ & $775 \quad(73)^{1}$ & $0,9(0,3)$ \\
\hline $\begin{array}{l}\text { Supraterapeutisk } \\
15<x<40 \mathrm{nmol} / \mathrm{l}\end{array}$ & 1160 & $(72)$ & $22(5)$ & $\begin{array}{l}\text { Supraterapeutisk } \\
1,3<\times<3 \mathrm{nmol} / \mathrm{l}\end{array}$ & $261 \quad(25)^{1}$ & $1,8(0,4)$ \\
\hline Toksisk $\geq 40 \mathrm{nmol} / \mathrm{l}$ & 17 & (1) & $48(11)$ & Toksisk $\geq 3,0 \mathrm{nmol} / \mathrm{l}$ & $22 \quad(2)^{2}$ & $5,2(2,8)$ \\
\hline
\end{tabular}

Khikvadrattest $p<0,00001$ for fordelingene av antall digitoksin og digoksin

$2 \mathrm{P}=0,03$ for økning i antall i toksisk gruppe sammenlignet med økning i sammenslått terapeutisk og supraterapeutisk gruppe 
midler og gjenspeiler i liten grad problematikk knyttet til bytte av legemiddel. Inntak av digitoksin/digoksin i selvskadingsøyemed $(\mathrm{n}=16)$ ble ekskludert av samme grunn.

Totalt 254 (digitoksin $=76$, digoksin $=$ 178) henvendelser ble inkludert. Giftinformasjonen så en betydelig økning $i$ antall henvendelser angående forgiftning med digitalis $i$ forbindelse med overgang til digoksin (fig 2).

Serumkonsentrasjon var oppgitt i 197 av henvendelsene i perioden 2010-14 og var toksisk i henholdsvis 21/24 (88\%), 13/17 (76\%), 48/57 (84\%), 51/65 (78\%), 28/35 $(80 \%)$ av tilfellene. Gjennomsnittlig serumkonsentrasjon for digitoksin var $47 \mathrm{nmol} / 1$ (fra 6 til $167 \mathrm{nmol} / \mathrm{l}, \mathrm{n}=56$ ), gjennomsnittlig serumkonsentrasjon for digoksin var 5,1 $\mathrm{nmol} / \mathrm{l}$ (fra 1,2 til $19 \mathrm{nmol} / \mathrm{l}, \mathrm{n}=147)$. Ved seks henvendelser ble det oppgitt serumkonsentrasjon for både digitoksin og digoksin.

Henvendelser vedrørende digoksin, totalt 178 henvendelser for hele perioden, ble gjennomgått for å kartlegge årsak til overdosering. Årsaken var i 164 tilfeller kronisk overdosering (for høy dose over flere døgn). Kun 14 av henvendelsene skyldtes ett enkelt inntak. Ved kronisk overdosering registreres ikke rutinemessig årsak til overdosering $\mathrm{i}$ Giftinformasjonens database. Data knyttet til årsak til forgiftning er derfor mangelfull, men ved 23 av henvendelsene var det oppgitt at pasienten var feildosert, fra 2 til 10 ganger terapeutisk dose. I 10 av 23 tilfeller var dosen ti ganger terapeutisk dose. 15 pasienter hadde nyresvikt ved innleggelse.

\section{Bivirkningsmeldinger til RELIS}

Totalt mottok RELIS i perioden 2010-14 ni meldinger om bivirkninger med dødelig utfall, der digoksin eller både digitoksin og digoksin var vurdert som utløsende legemiddel (tab 1). I flere tilfeller var det avvik fra veiledning for bytte fra digitoksin til digoksin.

Totalt ble det mottatt 51 meldinger i perioden, og i 39 av meldingene hadde melder (helsepersonell) selv gitt opplysninger om at reaksjonene skyldtes bytte og/eller overdosering. De fleste pasientene var over 70 år gamle og hadde tilleggslidelser utover hjertesykdom, blant annet nyresvikt/redusert nyrefunksjon.

\section{Terapikontroll ved}

serumkonsentrasjonsmåling

Gjennomsnittlig alder på pasienter som fikk målt serumkonsentrasjon av digitoksin og/ eller digoksin, var 78 år (SD var 12), og det var en liten overvekt av kvinner. Vi fant at 1619 pasienter ble behandlet med digitoksin i perioden 1.1.2010-31.12.2012, mens 1058 pasienter ble behandlet med digoksin i perioden 1.1. 2012-31.12. 2014. Dette viser en nedgang på rundt $35 \% \mathrm{i}$ antall pasienter som fikk utført terapikontroll. Den gjennomsnittlige serumkonsentrasjonen for digitok-

Tabell 3 Farmakokinetiske data for digitoksin og digoksin $(2,10)$

\begin{tabular}{lll} 
& Digitoksin & Digoksin \\
Halveringstid & $4-9 \mathrm{~d} \varnothing \mathrm{gn}$ & $1,5-2 \mathrm{~d} \varnothing \mathrm{gn}$ (v/normal nyrefunksjon) \\
Proteinbinding i plasma & $97 \%$ & $25 \%$ \\
Eliminasjon ved metabolisme & $90 \%$ & $10 \%$ \\
Eliminasjon ved renal utskillelse & $5 \%$ & $80 \%$ \\
Distribusjonsvolum & $0,5 \mathrm{l} / \mathrm{kg}$ & $5 \mathrm{l} / \mathrm{kg}$ \\
Biotilgjengelighet & $>90 \%$ & $60-80 \%$ \\
Terapeutisk plasmakonsentrasjon & $8-15 \mathrm{nmol} / \mathrm{l}$ & $0,6-1,3 \mathrm{nmol} / \mathrm{l}$ \\
\hline
\end{tabular}

sin var 19 (SD var 7) nmol/l og for digoksin $1,2$ (SD var $0,8 \mathrm{nmol} / \mathrm{l})$ i de aktuelle periodene. I perioden $2010-12$ hadde $73 \%$ av pasientene serumkonsentrasjon av digitoksin over terapiområdet og kun $27 \%$ innen terapiområdet. Etter byttet til digoksin var det kun $27 \%$ pasienter med serumkonsentrasjon av digoksin over terapiområdet (tab 2). I en khikvadrattest av fordelingene av digitoksin og digoksin får vi $\mathrm{p}<0,00001$.

Det var $1 \%$ pasienter med prøver i «toksisk» område for digitoksin og $2 \%$ for digoksin i de aktuelle periodene. Når vi sammenligner økningen i antall pasienter i gruppen toksiske med antallet $\mathrm{i}$ gruppen terapeutisk og supraterapeutisk (slått sammen i en gruppe), får vi en signifikant økning ( $p=0,03$, khikvadrattest). 12 av 22 pasienter med serumkonsentrasjon i det toksiske måleområdet av digoksin, var målt i prøver i 2012.

Vi dokumenterte kryssreaksjon med digitoksin på digoksinmetoden selv i terapeutisk område, gjennomsnittlig 3,5\%. Imidlertid fant vi ingen kryssreaktivitet for digoksinkonsentrasjoner $\mathrm{i}$ og over terapiområdet på digitoksinmetoden. Kryssreaktivitet ble testet i serum som ga et stort utslag («spiked») i en fortynningsrekke med digitoksin, digoksin eller begge legemidler samtidig. Data er ikke vist $i$ dette arbeidet. Det er ikke ekskludert for dette i prøvesvarene ettersom det sjelden ble målt digitoksin og digoksin i samme prøve.

Samtidig høye målinger av begge legemidlene ble funnet hos flere pasienter. Hovedparten av disse pasientene ble identifisert i 2012. Noen av disse funnene kan forklares av interferens på analysemetoden, men ikke alle funnene. I to av tilfellene hadde vi også opplysninger fra lege og legemiddelkurve om at pasientene hadde fått begge legemidler samtidig.

\section{Konklusjon}

Studien viser en liten forbigående, men signifikant økning i antall rapporterte forgiftninger, vesentlig i 2012 og 2013, samt en økning i rapporterte dødsfall med digitalis i forbindelse med overgangen til digoksin. Antall pasienter som fikk forskrevet digitalis, ble redusert med $25 \%$ i perioden, og etter overgangen til digoksin var en større andel av pasientprøvene i terapeutisk område.

Tilfellene med forgiftning er forårsaket av blant annet feildosering ved oppstart eller samtidig bruk/for kort utvaskingstid før oppstart med digoksin. I majoriteten av forgiftningene er årsaken ukjent. Gradvis eller akutt sviktende nyrefunksjon i etterkant av byttet eller eventuelt introduksjon av nye legemidler kan ha forårsaket nedsatt eliminasjon og påfølgende akkumulering. Hvis så er tilfelle, skyldes forgiftningene farmakokinetiske egenskaper ved digoksin i seg selv, og er ikke direkte knyttet til byttet (tab 3).

Metodologisk er studien beheftet med noen svakheter. Henvendelser til Giftinformasjonen og RELIS er basert på at helsepersonell eller pasienter «melder» hendelsen til Giftinformasjonen eller RELIS. Forgiftningstilfeller behandles i helsevesenet uten at Giftinformasjonen kontaktes. Generelt er rapporteringsfrekvensen på bivirkninger lav. Norske studier viste $1-10 \%$ for ikke-fatale bivirkninger og 30-50\% for fatale bivirkninger hos pasienter innlagt i sykehus $(14,15)$. Økt søkelys fra helsemyndigheter og medier rundt forgiftningsrisikoen ved bytte til digoksin kan ha forårsaket økt rapportering i seg selv. På den annen side er majoriteten av pasientene på digitalis eldre personer med betydelig komorbiditet, noe som øker risikoen for at digitalisrelaterte dødsfall ikke ble identifisert.

Det er overlappende pasientmateriale i de tre datakildene, men hver enkelt kilde kan ses på som separate signaler om en økning i antall forgiftninger.

Rene overdoseringer kan skyldes misforståelser mellom forskriver og pasient, ren menneskelig svikt ved forskrivning eller svikt ved legemiddelhåndteringen enten hjemme hos pasienten, på sykehjem eller i sykehus. Ved ti av overdoseringene rapportert til Giftinformasjonen ble det gitt ti ganger terapeutisk dose, noe som styrker mistanken om at det er blitt gjort feil ved utreg- 
ning av dosen til pasienten. Uvant dosering av digoksin kan ha forårsaket en økt frekvens av utregningsfeil.

Lanoxin var eneste digoksinpreparat markedsført i Norge før mai 2012 og ble kun levert i styrken $0,25 \mathrm{mg}$. Dette medførte at en del pasienter måtte dele tablettene, noen ganger i fire deler for å få rett dose. Høy tablettstyrke kan ha redusert sannsynligheten for at feilutregning oppdages, da antall tabletter ikke nødvendigvis blir påfallende høyt. Deling av tabletter kan være et problem i seg selv i forhold til etterlevelse, spesielt $i$ en eldre pasientgruppe.

I løpet av våren 2012 kom digoksinpreparater på markedet med styrkeangivelse i mikrogram (Digoxin «Nycomed»), mens andre preparater (Lanoxin) har styrkeangivelse $\mathrm{i}$ milligram. Det er naturlig å se dette i sammenheng med en økning $\mathrm{i}$ antall feildoseringer. Begge preparatene er fremdeles på markedet, og styrkeangivelsen bør standardiseres for å redusere risikoen for feildosering.

Alle tre datakildene inneholdt informasjon om pasienter som samtidig har hatt høye serumkonsentrasjoner av både digitoksin $\mathrm{og}$ digoksin. Om dette skyldes samtidig bruk, oppstart på digoksin uten utvasking av digitoksin, at den anbefalte utvaskingstiden var for kort for noen pasienter, eller om noe kan skyldes krysseraktivitet av digitoksin på digoksin målemetode, vet vi ikke. Litteratur antyder imidlertid at halveringstiden for digitoksin hos pasienter i 80-90-årene kan være betydelig forlenget med en halveringstid $\left(\mathrm{t}_{1 / 2}\right)$ på $25 \pm 9$ dager (16). Mange av pasientene gikk sannsynligvis inn i skiftet med høyt nivå av s-digitoksin da $73 \%$ av digitoksinprøvene, analysert ved Oslo universitetssykehus i 2010-12, var over anbefalt terapiområde (tab 2). Forlenget eliminasjon sammen med en høy serum-digitoksin kan være årsaken til at enkelte pasienter fikk for kort utvaskingstid før oppstart på digoksin. Mange av disse pasientene kunne med fordel fătt serumkonsentrasjonen monitorert under nedtrappingen av digitoksin - før de begynte med digoksin.

Veilederne som Legemiddelverket utarbeidet, ble publisert på legemiddelverkets hjemmeside og i Tidsskriftet. I hvilken grad denne informasjonen nådde legene som skulle foreta byttet, er uvisst. Byttet ble imidlertid omtalt i mediene etter et dødsfall våren 2012, og i etterkant av presseomtalen må man anta at helsepersonell i større grad var orientert om byttet og risikoen knyttet til dette.

I ettertid er det mye vi kan lære av dette legemiddelskiftet. Informasjonen i første veileder kunne vært mer gjennomarbeidet, jamfør behovet for en oppdatert veileder med blant annet reduksjon i dosering. Man kan også stille spørsmål ved om utvaskingstiden for digitoksin var tilstrekkelig lang for alle pasienter, og om man rutinemessig burde anbefalt måling av s-digitoksin før oppstart med digoksin.
Synonympreparater med forskjellig styrkeangivelse utgjør en sikkerhetsrisiko og bør standardiseres til én styrkeangivelse, samtidig som praktiske/relevante tablettstyrker bør være markedsført.

Det ble også avdekket mangelfull planlegging og beredskap under skiftet til digoksin. Flere sykehus hadde ikke analysemetoder for digoksin da skiftet startet, og det ble avdekket noe kryssreaktivitet av digitoksin på digoksinmetoden, selv innen terapiområdet. Monitorering av serumkonsentrasjon er viktig ved dosering av digitalis på grunn av smalt terapeutisk vindu, og manglende mulighet for monitorering vanskeliggjør et trygt skifte.

I mars 2012 oppsto det mangel på antidotene Digifab og Digibind på grunn av stort forbruk i Norge. Det er ikke kjent om dette fikk alvorlige konsekvenser for forgiftningspasientene, men viser manglende beredskap for en økning i antall forgiftninger i forbindelse med en overgang.

For fremtidige legemiddelbytter foreslår vi at det nedsettes en tverrfaglig gruppe som planlegger og følger situasjonen tett for å kunne gi rask, koordinert og oppdatert informasjon underveis for å trygge pasientbehandlingen. Det er viktig at instrukser for bytter er enkle og trygge å gjennomføre.

\section{Christian Haga (f. 1972)}

er cand.pharm. og seniorrådgiver.

Forfatter har fylt ut ICMJE-skjemaet og oppgir ingen interessekonflikter.

\section{Mimi Stokke Opdal (f. 1959)}

er overlege og førsteamanuensis II.

Forfatter har fylt ut ICMJE-skjemaet og oppgir ingen interessekonflikter.

\section{Silja Skogstad Tuv (f. 1976)}

er spesialist i klinisk farmakologi og overlege. Forfatter har fylt ut ICMJE-skjemaet og oppgir ingen interessekonflikter.

\section{Per-Henrik Zahl (f. 1961)}

er dr.med. i biostatistikk.

Forfatter har fylt ut ICMJE-skjemaet og oppgir

ingen interessekonflikter.

\section{Hanne Stenberg-Nilsen (f. 1964)}

er cand.pharm. og spesialrådgiver.

Forfatter har fylt ut ICMJE-skjemaet og oppgir

ingen interessekonflikter.

\section{Litteratur}

1. Skomedal T, Osnes JB. Endring av anbefalt terapeutisk serumkonsentrasjonsområde for digoksin og digitoksin. Hjerteforum 2007; 4: 27-31.

2. Madsen S. Digitalis and diabetes. Tidsskr Nor Legeforen 2012; 132: 1105

3. Madsen S, Claesson U, Wesenberg GR et al. Legemiddelmangel - årsaker og tiltak. Tidsskr Nor Legeforen 2012; 132: 2154-5.

4. Statens legemiddelverk. Overgang fra digitoksin til digoksin hos voksne. https://legemiddelverket.no/ nyheter/overgang-fra-digitoksin-til-digoksin-hosvoksne (8.7.2016).

5. Statens legemiddelverk. Nytt om legemidler. Praktiske råd for overgang fra digitoksin til digoksin hos voksne. Tidsskr Nor Legeforen 2012; 132: 21.

6. Statens legemiddelverk. Nytt om legemidler. Overgang fra digitoksin til digoksin hos voksne. Tidsskr Nor Legeforen 2012; 132: 641.

7. Statens legemiddelverk. Nytt om legemidler. Praktiske råd for overgang fra digitoksin til digoksin hos voksne. Tidsskr Nor Legeforen 2011: 131: 2445 .

8. Folkehelseinstituttet. Reseptregisteret. www.reseptregisteret.no (8.7.2016).

9. Vivo RP, Krim SR, Perez J et al. Digoxin: current use and approach to toxicity. Am J Med Sci 2008: 336: $423-8$

10. Norsk legemiddelhåndbok for helsepersonell 2013. Bergen: Fagbokforlaget Vigmostad \& Bjørke, 2013: 1122

11. Baselt RC. Disposition of toxic drugs and chemicals in man. 9. utgave. Seal Beach, CA: Biomedical Publications, 2011: 505-510.

12. Adams KF Jr, Patterson JH, Gattis WA et al. Relationship of serum digoxin concentration to mortality and morbidity in women in the digitalis investigation group trial: a retrospective analysis. J Am Coll Cardiol 2005; 46: 497-504.

13. Schulz M, Iwersen-Bergmann S, Andresen $\mathrm{H}$ et al. Therapeutic and toxic blood concentrations of nearly 1,000 drugs and other xenobiotics. Crit Care 2012; 16: R136.

14. Buajordet I, Ebbesen J, Erikssen J et al. Forekomst, rapportering og klassifisering av legemiddelrelaterte dødsfall. Tidsskr Nor Lægeforen 1995; 115: $2373-5$.

15. Ebbesen J, Buajordet I, Erikssen J et al. Drugrelated deaths in a department of internal medicine. Arch Intern Med 2001: 161: 2317-23.

16. Bøhmer T, Røseth A. Prolonged digitoxin half-life in very elderly patients. Age Ageing 1998; 27: 222-4.

Mottatt 5.2. 2015, første revisjon innsendt 17.6. 2015, godkjent 8.7. 2016. Redaktør: Tor Rosness. 